\section{Carbon isotope discrimination in C3 land plants is independent of natural variations in $\mathrm{p}_{\mathrm{CO} 2}$}

\section{M.J. Kohn ${ }^{1 *}$}

open 2 access

\section{Abstract}

The $\delta^{13} \mathrm{C}$ of terrestrial C3 plant tissues and soil organic matter is important for understanding the carbon cycle, inferring past climatic and ecological conditions, and predicting responses of vegetation to future climate change. Plant $\delta^{13} \mathrm{C}$ depends on the $\delta^{13} \mathrm{C}$ of atmospheric $\mathrm{CO}_{2}$ and mean annual precipitation (MAP), but an unresolved decades-long debate centres on whether terrestrial $\mathrm{C} 3$ plant $\delta^{13} \mathrm{C}$ responds to $\mathrm{p}_{\mathrm{CO} 2}$. In this study, the $\mathrm{p}_{\mathrm{CO} 2}$-dependence of $\mathrm{C} 3$ land plant $\delta^{13} \mathrm{C}$ was tested using isotopic records from low- and high-p historical through Eocene data. Historical data do not resolve a clear $\mathrm{p}_{\mathrm{CO}}$-effect $(-1.2 \pm 1.0$ to $0.6 \pm 1.0 \% / 100 \mathrm{ppmv})$. Organic carbon records across the Pleistocene-Holocene transition to $0.6 \pm 1.0 \%$ affected by changes in $\mathrm{MAP}$, carbon sources, and potential differential degradation to (o quantify $\mathrm{PCO}_{\text {CO- }}$-efects directly, but himits of $\leq 1.0 \% / 100 \mathrm{ppmv}$ or $\sim 0 \% / 100 \mathrm{ppmv}$ are permis. $-0.03 \pm 0.24 \%$ and tooth enamel data constrain peoz entects most tightly to $-0.03 \pm 0.13$ a preferred value of $0.0 \pm 0.3 \% / 100 \mathrm{ppmv}$ ( 2 s.e.). Recent models of $\mathrm{pCO}_{\mathrm{CO}}$-dependence imply unrealistic MAP for Cenozoic records.

Received 7 July 2015 | Accepted 3 December 2015 | Published 11 January 2016

\section{Introduction}

C3 plants (trees, shrubs, herbs and cool-climate grasses) constitute c. $95 \%$ of terrestrial plant biomass (Still et al., 2003), so understanding C3 plant response to changes in the partial pressure of atmospheric $\mathrm{CO}_{2}\left(\mathrm{p}_{\mathrm{CO}_{2}}\right)$ is key for modelling Earth's carbon cycle (e.g., Cao et al., 2010; Shevliakova et al., 2013). Carbon isotope compositions $\left(\delta^{13} \mathrm{C}\right)$ of $\mathrm{C} 3$ plants are a principal means of inferring water use efficiency (Farquhar et al., 1989), which is important to models of future C3 biomass, and have been proposed to allow estimation of mean annual precipitation (MAP) in the geologic past (Kohn, 2010). Plant $\delta^{13} \mathrm{C}$ depends on the $\delta^{13} \mathrm{C}$ of

atmospheric $\mathrm{CO}_{2}$ (Freyer and Wiesberg, 1973), but an unresolved decades-long debate centres on whether terrestrial $\mathrm{C} 3$ plant $\delta^{13} \mathrm{C}$ responds to $\mathrm{p}_{\mathrm{CO} 2}$. Many studies have argued that increasing $\mathrm{p}_{\mathrm{CO} 2}$ increases carbon isotope discrimination (e.g., Feng and Epstein, 1995; Schubert and Jahren, 2012); others have argued

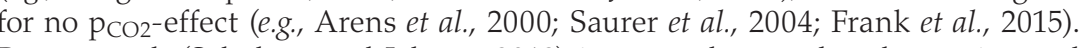
Recent work (Schubert and Jahren, 2012) integrated natural and experimental data to infer that $\mathrm{C} 3$ plant $\delta^{13} \mathrm{C}$ depends hyperbolically on $\mathrm{p}_{\mathrm{CO} 2}$ (Fig. 1a) and that changes to carbon isotope compositions in leaves and sediment organic matter over the last $30 \mathrm{ka}$ parallel and predict $\mathrm{p}_{\mathrm{CO} 2}$ (Schubert and Jahren, 2015). In this study, carbon isotope records ranging from the last several decades through the early Cenozoic are critically evaluated to identify which records indeed provide quantitative constraints on $\mathrm{p}_{\mathrm{CO} 2}$-dependencies, and to provide a robust estimate of that dependence.

Multiple factors besides atmospheric $\mathrm{CO}_{2}$ can affect $\mathrm{C} 3$ plant $\delta^{13} \mathrm{C}$, including MAP, ontogeny, light levels, genetics and fertilisation (e.g., through atmospheric nitrogen deposition; Farquhar et al., 1989; Stewart et al., 1995; McCarroll and Loader, 2004; Diefendorf et al., 2010; Kohn, 2010; Fig. 1b). Other physical factors, including latitude and altitude, have a minor impact on C3 plant $\delta^{13} \mathrm{C}$ (Diefendorf et al., 2010; Kohn, 2010), but high variability both within and among trees must reflect individual responses to other, less easily identified, environmental or physiological factors (McCarroll and Loader, 2004). Thus, records of natural $\delta^{13} \mathrm{C}$ through time, e.g., from tree rings, sediment records, etc. must account for changes to MAP and other environmental changes, most recently from anthropogenic activities, before any $\mathrm{p}_{\mathrm{CO} 2}$-dependence can be quantified.

"Modern" conditions anchor many quantitative estimates of palaeoclimate, e.g. $\delta^{13} \mathrm{C}$-based estimates of MAP are normalised to AD 2000 data $\left(\mathrm{p}_{\mathrm{CO} 2}=370\right.$ ppmv, $\delta^{13} \mathrm{C}_{\mathrm{CO} 2}=-8.0 \%$ o). If $\mathrm{C} 3$ plant $\delta^{13} \mathrm{C}$ does depend on $\mathrm{p}_{\mathrm{CO} 2}, \delta^{13} \mathrm{C}$ values from periods of low $\mathrm{p}_{\mathrm{CO} 2}$ (e.g., late Pleistocene) are anomalously high, and must be downward corrected for any calculations $\left(\Delta^{13} \mathrm{C}\right.$ increases); conversely $\delta^{13} \mathrm{C}$ values from periods of high $\mathrm{p}_{\mathrm{CO} 2}$ (e.g., Eocene) must be upward corrected $\left(\Delta^{13} \mathrm{C}\right.$ decreases; Fig. 1a). In comparison with the modern dependence of C3 plant $\delta^{13} \mathrm{C}$ on MAP (Fig. 1b), uncorrected estimates of MAP must be too dry for the Pleistocene and too wet for the Eocene. Fortunately, estimates of MAP for many times are known from independent proxies (e.g., floral analysis) and general circulation models, and $\mathrm{p}_{\mathrm{CO} 2}$ is known either from measurements in ice cores or from geochemical proxies. Thus, $\mathrm{p}_{\mathrm{CO} 2}$-effects on $\mathrm{C} 3 \delta^{13} \mathrm{C}$ values can now be evaluated from ancient sediments and fossils, albeit with careful consideration of sometimes substantial errors in proxy estimates of $\mathrm{P}_{\mathrm{CO} 2}$ and MAP (see Supplementary Information)

This study evaluates $\mathrm{p}_{\mathrm{CO} 2}$-dependencies in the context of two endmember models - a null hypothesis of no dependence vs. a hyperbolic dependence that integrates numerous other studies (Schubert and Jahren, 2012). Ultimately four datasets are considered: modern leaves (1970 through 2007; Kohn, 2010), tropical rainforest tree rings (least susceptible to changes in MAP; Fig. 2a; 
van der Sleen et al., 2015), sediment organic matter (SOM) from three representative studies of the Pleistocene-Holocene transition (Fig. 2b,c; Hatté et al., 1998 Sinninghe Damsté et al., 2011; Barker et al., 2013), and herbivore collagen and tooth enamel for especially low-p $\mathrm{PO}_{\mathrm{CO}}(<250 \mathrm{ppmv})$ and high-p $\mathrm{p}_{\mathrm{CO} 2}(>500 \mathrm{ppmv})$ periods of the geologic past (Fig. 3; Supplementary Information). The overall intent of these comparisons is to correct first for factors that we know influence $\delta^{13} \mathrm{C}$ (especially MAP, carbon sources) and ascribe any residual effect to $\mathrm{p}_{\mathrm{CO} 2}$.
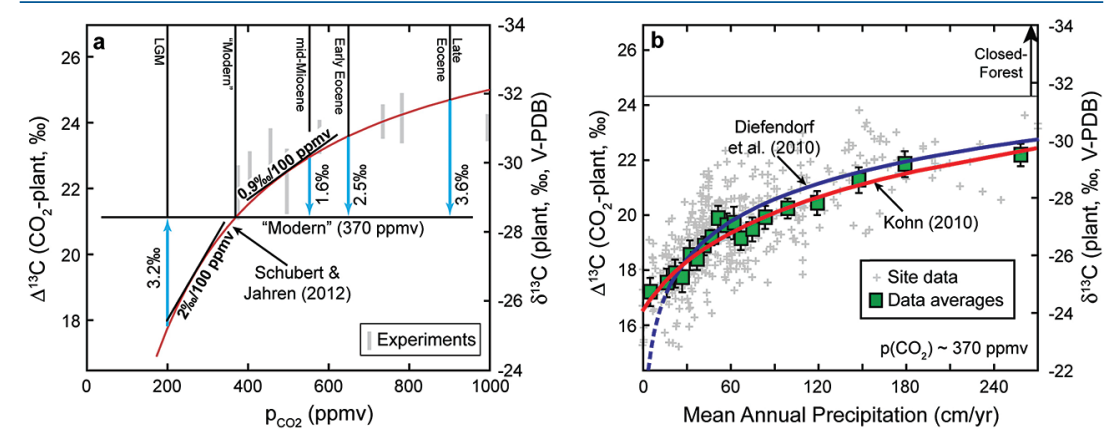

Figure 1 Proposed models for factors that influence $\delta^{13} \mathrm{C}$ of $\mathrm{C} 3$ plants. (a) $\mathrm{p}_{\mathrm{CO} 2}$. Differences are illustrated between geological conditions vs. $\mathrm{AD} 2000\left(\mathrm{p}_{\mathrm{CO} 2}=370 \mathrm{ppmv}\right.$, average $\delta^{13} \mathrm{C}=-28.5$ for $\mathrm{C} 3$ biomass). $\mathrm{LGM}=$ Last Glacial Maximum. Note inverse relationship between $\delta^{13} \mathrm{C}$ and $\Delta^{13} \mathrm{C}$. Experiments are for a $\Delta^{13} C$. Experiments are for above ground biomass (Schubers and Jahren, 2012), shifted to fit
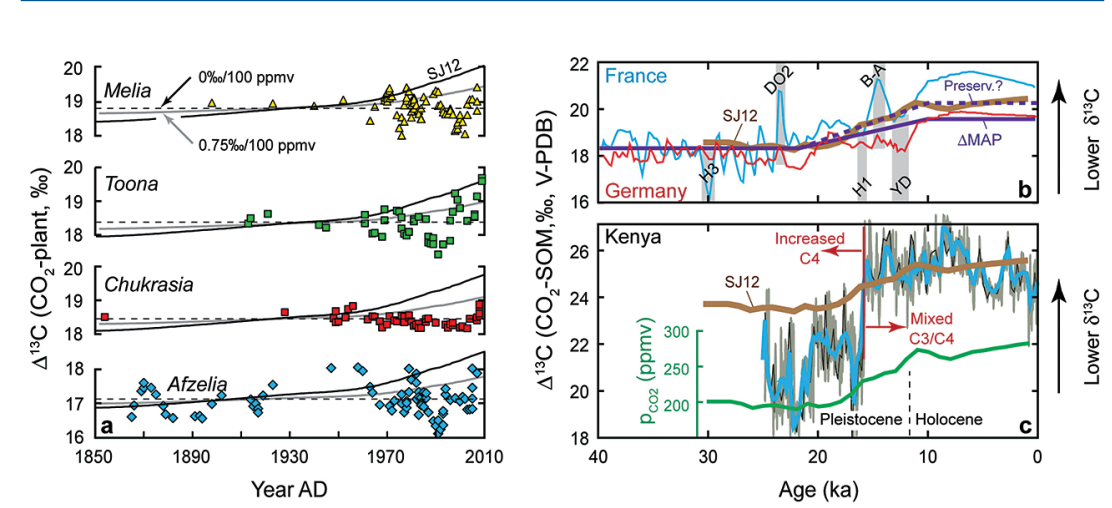

Figure 2 Tree ring and Pleistocene-Holocene records. (a) Tropical data from Thailand show near-zero $\mathrm{p}_{\mathrm{CO} 2}$ effect. Models are anchored on oldest 5-10 analyses (where any $\mathrm{p}_{\mathrm{CO} 2}$ effects should be smallest). SJ12 = model of Schubert and Jahren (2012). (b) Correction for changes in mean annual precipitation ("$\triangle \mathrm{MAP}$ "), and possibly for organic matter preservation ("preserv.") reproduces records independent of a direct $\mathrm{p}_{\mathrm{CO}^{2}}$-dependence. Brief climatic events also correlate with changes in $\Delta^{13} \mathrm{C}$ independent of $\mathrm{p}_{\mathrm{CO} 2} . \mathrm{H1}, \mathrm{H3}=$ Heinrich events 1 and 3; DO2 Dansgaard-Oeschger event 2; B-A = Bølling-Allerød; $Y D=$ Younger Dryas. (c) An abrupt shift at C. 15.8 ka could reflect an abrupt threshold response of C4 biomass in the local ecosystem or variable contributions of diatoms to SOM (Fig. S-1)
Because plants track the $\delta^{13} \mathrm{C}$ of atmospheric $\mathrm{CO}_{2}$, which has changed through time, data are presented in terms of isotope discrimination $\left(\Delta^{13} \mathrm{C}\right)$

$$
\left.\Delta^{13} \mathrm{C}\left(\mathrm{CO}_{2}\right)-i\right)=\frac{\delta^{13} \mathrm{C}_{\mathrm{CO} 2}-\delta^{13} \mathrm{C}_{i}}{1+\delta^{13} \mathrm{C}_{i} / 1000}
$$

By correcting for secular changes to atmospheric $\delta^{13} \mathrm{C}$ from recent direct measurements, ice core measurements, and foraminiferal data (Supplementary Information), Equation 1 allows comparisons of data from different times.

Supplementary Information explains materials and methods, including error propagation

\section{Results and Discussion}

Modern/Historical records. Linear regression of modern leaf $\Delta^{13} \mathrm{C}(\mathrm{Kohn}, 2010)$ treating $\mathrm{P}_{\mathrm{CO} 2}$ as an independent variable (Table $\mathrm{S}-1$ ), results in a $\mathrm{P}_{\mathrm{CO}}$ coefficient for $\Delta^{13} \mathrm{C}$ of $-1.2 \pm 1.0 \%$ o/100 ppmv $(2 \sigma)$. These data do not generally support a positive $\mathrm{p}_{\mathrm{CO} 2}$-dependence for $\Delta^{13} \mathrm{C}$ but are quite imprecise. Historical cellulose data from tropical rainforests (Fig. 2a; van der Sleen et al., 2015; Table S-1) suggest a positive slope with respect to $\mathrm{p}_{\mathrm{CO} 2}(0.62 \pm 1.05 \%$ o/100 ppmv, 2 s.e. Supplementary Information), but are also strongly influenced by an up-tick in $\Delta^{13} \mathrm{C}$ between 2000 and $2010 \mathrm{AD}$ (Fig. 2a; Toona, Chukrasia), which might reflect other factors. For example, 10-20 yr, 1-2 \%o oscillations at all sites (e.g., Melia Afzelia, Fig. 2a) probably reflect susceptibility to environmental factors besides precipitation and $\mathrm{p}_{\mathrm{CO} 2}$, and such an effect might explain specific slopes. Tree ring isotope data across Europe, corrected for climate variables, suggest a negative $\mathrm{p}_{\mathrm{CO} 2}$-dependence $(-0.55 \pm 0.67 \% \mathrm{\%} / 100 \mathrm{ppmv}$; data from Frank et al., 2015). Overall, modern/historical data are too imprecise and idiosyncratic to either require or preclude a $\mathrm{p}_{\mathrm{CO} 2}$-effect.

Pleistocene-Holocene sediment records. Mid-latitude sediments from the Rhine River valley in France and Germany present one of the better cases for a $\mathrm{p}_{\mathrm{CO} 2}$-effect: a gradual $2 \%$ increase in $\Delta^{13} \mathrm{C}$ between 20 and 10 ka parallels $\mathrm{p}_{\mathrm{CO} 2}$ (Fig. 2b). A near doubling of MAP across the Pleistocene-Holocene transition (Bartlein et al., 2011; Alder and Hostetler, 2015), however, predicts c. $1.25 \%$ of the observed $\sim 2 \%$ increase (Fig. 2b), so any $\mathrm{P}_{\mathrm{CO} 2}$-effect must be $\leq \sim 1.0 \%$ o/100 ppmv. In addition, organic $\mathrm{C}$ content in these records increases by a factor of 9 across the Pleistocene-Holocene boundary (Hatté et al., 1998). Numerous studies show a linear correlation between $\Delta^{13} \mathrm{C}$ and the logarithm of soil organic $\mathrm{C}$ content, (e.g. Poage and Feng, 2004) with a minimum slope of c. $0.7 \%$ per $\log _{10}[\mathrm{C}]$ (Balesdent et al., 1993). If the striking increase in organic $C$ content in the European records represents differential degradation, $\Delta^{13} \mathrm{C}$ should increase by at least c. $0.65 \%$ The combined isotopic effects of changes to MAP and organic C content (c. $2 \%$ ) can explain the data without resort to any $\mathrm{p}_{\mathrm{CO} 2}$-effects. 
Alternatively, an estimate of ecosystem impacts on $\Delta^{13} \mathrm{C}$ can be made for the French record in reference to the Dansgaard-Oeschger 2 (DO2) and the Bølling-Allerød (B-A) warming events, which caused brief 2-2.5\% spikes in $\Delta^{13} \mathrm{C}$ without obvious changes to $\mathrm{p}_{\mathrm{CO} 2}$. Subtracting this ( $\mathrm{p}_{\mathrm{CO} 2}$-independent) effect from the Pleistocene-Holocene transition yields a residual $\mathrm{p}_{\mathrm{CO} 2}$-effect of $\sim 0 \%$ o/100 ppmv.

A large, abrupt increase in $\Delta^{13} \mathrm{C}$ in low-latitude Kenyan lake data (Fig. 2c) likely reflects decreasing abundances of C4 vegetation (Sinninghe Damsté et al., 2011), rather than increasing $\mathrm{p}_{\mathrm{CO} 2}$. Increasing $\mathrm{p}_{\mathrm{CO} 2}$ tends to destabilise $\mathrm{C} 4$ plants (Ehleringer et al., 1997), so an abrupt decrease in C4 abundance (Prentice et al., 2011) during the Pleistocene-Holocene rise in $\mathrm{p}_{\mathrm{CO} 2}$ logically explains the observations. Changes to lake diatom abundance and preservation may also play a role (Fig. S-1).

Overall, for the Pleistocene-Holocene transition, widespread increases in MAP across much of Earth (Bartlein et al., 2011) and concomitant changes to floral ecosystems (CLIMAP, 1976; Prentice et al., 2011), especially changes in C3/ $\mathrm{C} 4$ abundances at low latitudes, generally predict an increase in $\Delta^{13} \mathrm{C}$, compromising any quantitative retrieval or validation of $\mathrm{p}_{\mathrm{CO} 2}$-dependencies using these records. At present, the best constrained data imply a maximum value of $\leq 1$. 0 $\%$ o/100 ppmv (MAP-correction alone) or possibly 0.0 \%o/100 ppmv (DO-event analog, France; MAP plus organic $C$ degradation) between 180 and 270 ppmv.

Fossil herbivore records. Pleistocene and Tertiary herbivore data place the most stringent constraints on a $\mathrm{p}_{\mathrm{CO} 2}$-dependence: $-0.03 \pm 0.13 \% / 100 \mathrm{ppmv}$ between 180 and 370 ppmv, and $-0.03 \pm 0.24 \% / 100$ ppmv between 370 and 715 ppmv. The $\mathrm{p}_{\mathrm{CO} 2}$-dependent model strongly overestimates $\Delta^{13} \mathrm{C}$ for the Pleistocene and underestimates $\Delta^{13} \mathrm{C}$ for the Tertiary (Fig. 3a,b). Similarly, isotopically-based estimates of MAP without correction of $\mathrm{p}_{\mathrm{CO} 2}$ reproduce independent estimates within uncertainties (Fig. 3c), whereas estimates from the $\mathrm{p}_{\mathrm{CO}}$ dependent model strongly overestimate MAP for Pleistocene data, and strongly

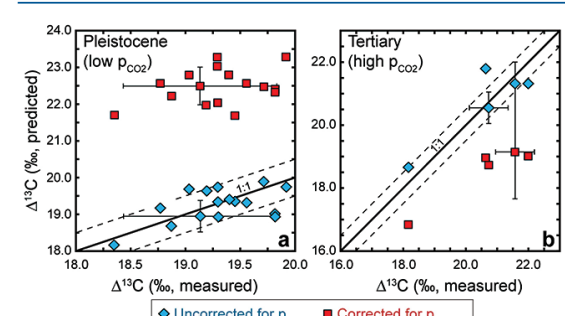

$\checkmark$ Uncorrected for $P_{002}-1$ Corrected for $P_{022}$

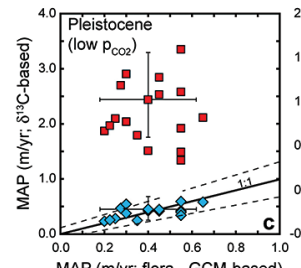
$\nabla$ Uncorrected for $P_{002}$

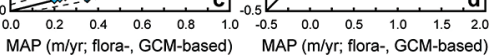

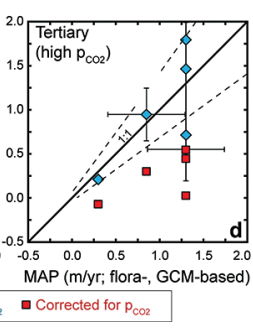

C Corrected for $\mathrm{P}_{\mathrm{POO}}$
Figure 3 Cenozoic herbivore data. (a-d) Calculated vs. measured $\Delta^{13} \mathrm{C}$, and calculated vs. independently estimated MAP, showing good correspondence with $\mathrm{p}_{\mathrm{CO} 2}$-independent model. Representative error bars $(2 \sigma)$ reflect propagated uncertainties in isotope compositions and tissue-diet fractionations, the dependence of $\delta^{13} \mathrm{C}$ on MAP, and proxy estimates of MAP and $\mathrm{p}_{\mathrm{CO} 2}$ (Table S-2). underestimate MAP for Tertiary data (Fig. 3d). Uncertainties in estimates of MAP, $\mathrm{p}_{\mathrm{CO} 2}$, or the $\delta^{13} \mathrm{C}$ of atmospheric $\mathrm{CO}_{2}$ do not likely bias interpretation of Pleistocene data because $\mathrm{p}_{\mathrm{CO} 2}$ and $\delta^{13} \mathrm{C}$ are directly determined from ice cores, and MAP is based on large numbers of floral observations coupled to GCM's with especially well constrained boundary conditions. Large errors for Tertiary $\mathrm{p}_{\mathrm{CO} 2}$ cause the $\mathrm{p}_{\mathrm{CO} 2}$-dependent model errors to overlap independent estimates of $\Delta^{13} \mathrm{C}$ and MAP. The point of overlap, however, occurs only at quasi-modern $\mathrm{p}_{\mathrm{CO} 2}$ levels, which is generally inconsistent with Eocene and middle Miocene proxies (Beerling and Royer, 2011). Note that a systematic error for Pleistocene calculations operates in the opposite direction for Tertiary data, so the internal consistency of both sets of calculations (the same $\mathrm{p}_{\mathrm{CO} 2}$ coefficient) suggests that systematic errors are small.

Considering calculated MAP throughout the Cenozoic, a U-shaped distribution (Fig. 4a) highlights unusually dry conditions [low $\Delta^{13} \mathrm{C}\left(\mathrm{CO}_{2}\right.$-plant), high $\delta^{13} \mathrm{C}$ (plant)] during the late Eocene and early/middle Oligocene. Aggregating Cenozoic MAP estimates, the $\mathrm{p}_{\mathrm{CO} 2}$-independent model exhibits a predominance of values between 0 and $1.0 \mathrm{~m} / \mathrm{yr}$ (>80\%; Fig. $4 \mathrm{~b}$ ) with a distribution that mimics modern Earth's area distribution of MAP (dashed line, Fig. $4 \mathrm{~b}$ ). In contrast, the $\mathrm{p}_{\mathrm{CO} 2}$-dependent model implies widespread rainforests during the Pleistocene (Fig. 4a), which contrasts starkly with global climate and vegetation syntheses that have long indicated greater aridity across much of the globe (e.g., CLIMAP, 1976; Prentice et al., 2011), especially in Europe where many of the Pleistocene fossils were collected. The $\mathrm{p}_{\mathrm{CO} 2}$-dependent model also implies negative MAP during the Eocene and Oligocene (Fig. 4a). A histogram of $\mathrm{p}_{\mathrm{CO} 2}$-dependent predictions (Fig. 4c) yields unrealistically abundant hyperarid deserts (MAP < $0)$ and rainforests $(>2.5 \mathrm{~m} / \mathrm{yr})$.

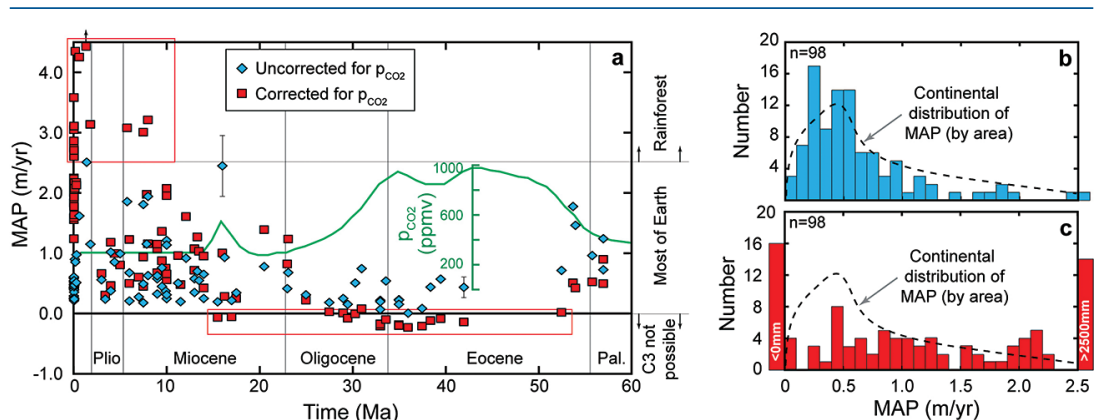
Figure 4 (a) Estimates of MAP for the Cenozoic based on fossil herbivore isotope compositions
show a U-shaped distribution. pCO2-corrections imply widespread rainforests in the Pleistocene, and hyper-deserts in mid-Cenozoic. pCO2 curve simplified from Beerling and Royer (2011). (b-c) Histograms of Cenozoic MAP estimates show a better match between the global distri(b-c) Hstograt The (b2and rainforests (MAP > $2.5 \mathrm{~m} / \mathrm{yr}$ ) in the geologic record. 


\section{Perspective and Recommendations}

As discussed elsewhere (Schubert and Jahren, 2012), studies investigating $\mathrm{P}_{\mathrm{CO} 2-}$ effects rarely account for other factors that may influence $\delta^{13} \mathrm{C}$, making crossstudy comparisons difficult. One recent study that did attempt to account for such factors (Frank et al., 2015) concluded that $\mathrm{p}_{\mathrm{CO} 2}$ has no effect on tree $\delta^{13} \mathrm{C}(-0.55 \pm$ $0.67 \%$ \% $/ 100$ ppmv; Supplementary Information), in good agreement with results here. Although susceptible to individual idiosyncrasies, cellulose records from individual trees from the Borneo rainforest (Loader et al., 2011; MAP c. $3 \mathrm{~m} / \mathrm{yr}$ ) also imply a $\mathrm{p}_{\mathrm{CO} 2}$-effect indistinguishable from zero $(0.0 \pm 0.2 \%$ o/ $100 \mathrm{ppmv}$; Supplementary Information). Early Eocene isotopes of angiosperms further support p $\mathrm{CO}_{\mathrm{C} 2}$-independence (Diefendorf et al., 2015). At present, the most discrepant study (Schubert and Jahren, 2012) represents short-term experiments on two forbs (Arabidopsis and radish). As discussed recently (Diefendorf et al., 2015; Voelker et al., 2015), plants may exhibit short-term phenotypic and isotopic changes in response to abrupt changes to $\mathrm{p}_{\mathrm{CO} 2}$, but on evolutionary timescales (decades to centuries) may evolve towards an optimal physiology whose isotopic fractionation is $\mathrm{p}_{\mathrm{CO} 2}$-independent. Short-term experiments might have relevance for modern rapid changes to $\mathrm{p}_{\mathrm{CO} 2}$, but not for ancient isotope records.

Overall, natural data either do not resolve a $\mathrm{P}_{\mathrm{CO} 2}$-dependence or indicate an effect far smaller than recent models. On geologic timescales, a best estimate for a $\mathrm{p}_{\mathrm{CO} 2}$-dependence between c. 200 and c. 700 ppmv averages $-0.04 \pm$

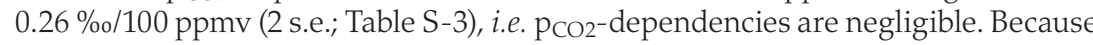
no correction for $\mathrm{p}_{\mathrm{CO} 2}$ is needed, this result vastly simplifies interpretations of past climates and carbon use by $\mathrm{C} 3$ land plants.

\section{Acknowledgements}

Funded by NSF grants EAR1251443 and EAR1349749. Comments from A. Diefendorf and detailed reviews from B. Schubert and an anonymous reviewer helped improve the MS, although Schubert does not necessarily agree with data selection, interpretations, or conclusions.

Editor: Bruce Watson

\section{Additional Information}

Supplementary Information accompanies this letter at www.geochemicalperspectivesletters.org/article1604

Reprints and permission information is available online at http://www. geochemicalperspectivesletters.org/copyright-and-permissions
Cite this letter as: Kohn, M.J. (2016) Carbon isotope discrimination in C3 land plants is independent of natural variations in $\mathrm{p}_{\mathrm{CO} 2}$. Geochem. Persp. Let. 2, 35-43.

\section{References}

AldeR, J.R., HosTETLER, S.W. (2015) Global climate simulations at 3000-year intervals for the last 21000 years with the GENMOM coupled atmosphere-ocean model. Climate of the Past 11, 449-471, doi: 10.5194/cp-11-449-2015

ARENS, N.C., JAHREN, A.H., AMUNDSON, R.G. (2000) Can C3 plants faithfully record the carbon isotopic composition of atmospheric carbon dioxide? Paleobiology 26, 137-164.

Balesdent, J., Girardin, C., Mariotti, A. (1993) Site-related $\delta^{13} \mathrm{C}$ of tree leaves and soil organic matter in a termperate forest. Ecology 74, 1713-1721, doi: 10.2307/1939930.

Barker, P.A., Hurrell, E.R., Leng, M.J., Plessen, B., Wolff, C., Conley, D.J., Keppens, E., Milne, I., Cumming, B.F., Laird, K.R., Kendrick, C.P., Wynn, P.M., Verschuren, D. (2013) Carbon cycling within an East African lake revealed by the carbon isotope composition of diatom silica: a 25-ka record from Lake Challa, Mt. Kilimanjaro. Quaternary Science Reviews 66, 55-63, doi: 10.1016/j.quascirev.2012.07.016

Bartlein, P.J., Harrison, S.P., Brewer, S., Connor, S., Davis, B.A.S., Gajewski, K., Guiot, J., Harrison-Prentice, T.I., Henderson, A., Peyron, O., Prentice, I.C., Scholze, M., Seppa, H., Shuman, B., Sugita, S., Thompson, R.S., Viau, A.E., Williams, J., Wu, H. (2011) Pollen-based continental climate reconstructions at 6 and 21 ka: a global synthesis. H. (2011) Pollen-based continental climate reconstructions at 6 an
Climate Dynamics 37, 775-802, doi: 10.1007/s00382-010-0904-1.

BeERLing, D.J., Royer, D.L. (2011) Convergent Cenozoic $\mathrm{CO}_{2}$ history. Nature Geoscience 4, 418-420

CaO, L., Bala, G., Caldeira, K., Nemani, R., BAN-Weiss, G. (2010) Importance of carbon dioxide physiological forcing to future climate change. Proceedings of the National Academy of Sciences 107, 9513-9518, doi: 10.1073/pnas.0913000107.

CLIMAP (1976) The surface of the Ice-Age Earth. Science 191, 1131-1137.

Diefendorf, A.F., Mueller, K.E., Wing, S.L., Koch, P.L., FreEMAN, K.H. (2010) Global patterns in leaf ${ }^{13} \mathrm{C}$ discrimination and implications for studies of past and future climate. Proceedings of the National Academy of Sciences 107, 5738-5743.

Diefendorf, A.F., Freeman, K.H., Wing, S.L., Currano, E.D., Mueller, K.E. (2015) Paleogene plants fraction
Letters $429,33-44$

EHLERINCER J R, CERLINC, TE, HELUKER, B.R. (1997) C-4 photosynthesis, atmospheric CO and climate. Oecologia 112, 285-299, doi: 10.1007/s004420050311.

FARQuHAR, G.D., EHLERINGER, J.R., HubicK, K.T. (1989) Carbon isotope discrimination and photosynthesis. Annual Review of Plant Physiology and Plant Molecular Biology 40, 503-537.

FENG, X., EPSTEIN, S. (1995) Carbon isotopes of trees from arid environments and implications for reconstructing atmospheric $\mathrm{CO}_{2}$ concentration. Geochimica et Cosmochimica Acta 59, 2599-2608.

Frank, D.C., Poulter, B., Saurer, M., Esper, J., Huntingford, C., Helle, G., Treydte, K. ZiMMERMANN, N.E., SCHLESER, G.H., AHLSTRÖM, A., CiaIS, P., FrIEDLINGSTEIN, P., Levis, S., LOMAS, M., Sitch, S., VIovy, N., Andreu-HaYles, L., BednarZ, Z Berninger, F., Boettger, T., D'Alessandro, C.M., Daux, V., Filot, M., Grabner, M., Gutierrez, E., Haupt, M., Hilasvuori, E., Jungner, H., Kalela-Brundin, M., Krapiec, M., Leuenberger, M., Loader, N.J., Marah, H., Masson-Delmotte, V., Pazdur, A., Panelczyk, S., Pierre, M., Planells, O., Pukiene, R., Reynolds-Henne, C.E., Rinne, K.T., SARAcino, A., Sonninen, E., Stievenard, M., Switsur, V.R., SzczePaneK, M., Szychowska-Krapiec, E., Todaro, L., Waterhouse, J.S., Weig, M. (2015) 
Water-use efficiency and transpiration across European forests during the Anthropocene. Nature Climate Change 5, 579-583, doi: 10.1038/NCLIMATE2614.

FREYER, H.D., WIESBERG, L. (1973) ${ }^{13} \mathrm{C}$ decrease in modern wood due to large-scale combustion of fossil fuels. Naturwissenschaften 60, 517-518.

Hatté, C., Fontugne, M., Rousseau, D.D., Antoine, P., Zoller, L., Tisnerat-Laborde, N., Bentaleb, I. (1998) $\delta^{13} \mathrm{C}$ variations of loess organic matter as a record of the vegetation response to climatic changes during the Weichselian. Geology 26, 583-586.

KoHN, M.J. (2010) Carbon isotope compositions of terrestrial C3 plants as indicators of (paleo)ecology and (paleo)climate. Proceedings of the National Academy of Sciences 107, 19691-19695.

LOADER, N.J., Walsh, R.P.D., RObertson, I., Bidin, K., Ong, R.C., Reynolds, G., McCarRoll, D., GAGEN, M., YounG, G.H.F. (2011) Recent trends in the intrinsic water-use efficiency of ringless rainforest trees in Borneo. Philosophical Transactions of the Royal Society B-Biological Science 366, 3330-3339.

MCCARROLL, D., LOADER, N.J. (2004) Stable isotopes in tree rings. Quaternary Science Reviews 23, 771-801, doi: 10.1016/j.quascirev.2003.06.017.

POAGE, M.A., FENG, X. (2004) A theoretical analysis of steady state $\delta^{13} \mathrm{C}$ profiles of soil organic matter. Global Biogeochemical Cycles, 18, doi: 10.1029/2003GB002195.

PRENTICE, I.C., HARRISON, S.P., BARTLEIN, P.J. (2011) Global vegetation and terrestrial carbon cycle changes after the last ice age. New Phytologist 189, 988-998.

Saurer, M., Siegwolf, R.T.W., Schweingruber, F.H. (2004) Carbon isotope discrimination indicates improving water-use efficiency of trees in northern Eurasia over the last 100 years. Global Change Biology 10, 2109-2120.

SCHUBERT, B.A., JAHREN, A.H. (2012) The effect of atmospheric $\mathrm{CO}_{2}$ concentration on carbon isotope fractionation in C3 land plants. Geochimica et Cosmochimica Acta 96, 29-43.

SCHUBERT, B.A., JAHREN, A.H. (2015) Global increase in plant carbon isotope fractionation following the Last Glacial Maximum caused by increase in atmospheric PCO2. Geology 43, 435-438.

Shevliakova, E., Stouffer, R.J., Malyshev, S., Krasting, J.P., Hurtt, G.C., Pacala, S.W (2013) Historical warming reduced due to enhanced land carbon uptake. Proceedings of the National Academy of Sciences 110, 16730-16735, doi: 10.1073/pnas.1314047110.

Sinninghe Damsté, J.S., Verschuren, D., Ossebaar, J., BlokKer, J., van Houten, R., van DER MeER, M.T.J., PlesSen, B., SCHOUten, S. (2011) A 25,000-year record of climate-induced changes in lowland vegetation of eastern equatorial Africa revealed by the stable carbonisotopic composition of fossil plant leaf waxes. Earth and Planetary Science Letters 302, 236-246,

SteWART, G.R., TuRnBULL, M.H., SCHMidT, S., ERSKINE, P.D. (1995) ${ }^{13}$ C natural abundance in plan communities along a rainfall gradient: a biological integrator of water availability. Australian Journal of Plant Physiology 22, 51-55.

Still, C.J., BerRY, J.A., CollatZ, G.J., DeFries, R.S. (2003) Global distributions of C3 and C4 vegetation: carbon cycle implications. Global Biogeochemical Cycles 17, doi: 10.1029/2001GB001807.

van Der Sleen, P., Groenendijk, P., Vlam, M., Anten, N.P.R., Boom, A., Bongers, F., Pons, T.L., TERBURG, G., ZUIDEMA, P.A. (2015) No growth stimulation of tropical trees by 150 years of $\mathrm{CO}_{2}$ fertilization but water-use efficiency increased. Nature Geoscience 8, 24-28.

Voelker, S.L., Brooks, J.R., Meinzer, F.C., Anderson, R., BAder, M.K, BatTipaglia, G. BeCKLin, K.M., BeERling, D., Bert, D., Betancourt, J.L., DAWSON, T.E., DOMEC, J.C. GuYette, R.P., Körner, C., LeavitT, S.W., Linder, S., Marshall, J.D., Mildner, M., Ogée, J., Panyushina, I., Plumpton, H.J., Pregitzer, K.S., Saurer, M., Smith, A.R. Siegwolf, R.T., Stambaugh, M.C., Talhelm, A.F., Tardif, J.C., van De Water, P.K., WARD, J.K., WINGATE, L. (2015) A dynamic leaf gas-exchange strategy is conserved in woody plants under changing ambient $\mathrm{CO}_{2}$ : evidence from carbon isotope discrimination in paleo and $\mathrm{CO}_{2}$ enrichment studies. Global Change Biology, doi: 10.1111/gcb13102. 